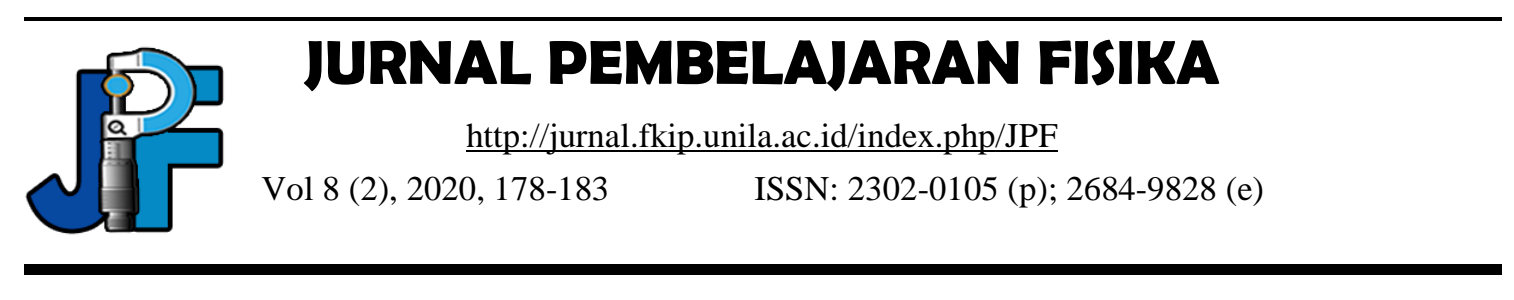

\title{
Effectiveness of Online-Based Physics Learning During Pandemic
}

\author{
Alpiana Hidayatulloh ${ }^{1}$, Hardani2 $^{*}$, Alpi Zaidah ${ }^{3}$, Muh. Iman Darmawan ${ }^{4}$ \\ ${ }^{1}$ Universitas Pendidikan Mandalika, Indonesia \\ ${ }^{2}$ Politeknik Medica Farma Husada Mataram, Indonesia \\ ${ }^{3}$ Institut Pendidikan Nusantara Global, Indonesia \\ ${ }^{4}$ Universitas Hamzanwadi, Indoneisa \\ *e-mail:danylastchild07@gmail.com
}

\begin{abstract}
This study aims to analyze the effectiveness of online learning in physics subjects. This study uses qualitative descriptive methods and data obtained by providing evaluation and observation tests. The subject of this study was grade $X$ as many as 18 students. To find out the effectiveness of online physics learning, an evaluation was carried out with an essay test of 5 questions and an observation sheet of 5 types of assessment. Then the results were analyzed by descriptive qualitative. Based on the results of the analysis, $27.8 \%$ got the moderate category, $61.1 \%$ got low scores and $11.1 \%$ got the very low category. Then for the student activity assessment sheet, there is $14.5 \%$ student attendance, $13 \%$ of students pay attention to the teacher's explanation, $2.8 \%$ of students and do other activities actively during the learning process, and $15 \%$ collect assignments. Online learning is ineffective in pandemics. The cause of the low percentage is due to the many obstacles faced by students in participating in online learning, one of which is the lack of supporting facilities for online learning.
\end{abstract}

Keywords: Effectiveness, Physics Learning, Online Learning, Pandemic

DOI: http://dx.doi.org/10.23960/jpf.v8.n2.202006 


\section{INTRODUCTION}

Indonesia is currently experiencing a health crisis because Indonesia is experiencing an outbreak of diseases caused by the virus, where the virus makes the public lack ampersands. After all, the spread is so fast, the virus is called the covid-19 virus or coronavirus (Sethy et al. 2020). Coronavirus is a type of virus that attacks the human respiratory system and causes death (Yuliana 2020). The virus attacks humans very quickly, in the event of contact with people exposed to the virus (Di Gennaro et al. 2020). So one of the government's efforts to prevent the spread of the virus is by doing social distancing. The government's efforts to have an impact on the education sector, namely the learning process of teaching in schools are tied. So the government, especially the education minister, took steps to determine how the roots of the education sector remained during the coronavirus outbreak. According to WHO, coronavirus is a virus that causes diseases in animals and humans that cause respiratory infections ranging from flu to more severe diseases. The virus attacks humans very quickly in case of contact with people exposed to the virus (WHO 2020).

As in other countries, cases of Covid-19 in Indonesia are also increasing with community activities. Based on the Ministry of Health's report, on August 30, 2020, there were 172.053 confirmed cases with a mortality rate of 7343 (CFR 4.3\%). DKI Jakarta has the most cumulative confirmed cases, namely 39.037 cases. The region with the fewest cumulative cases is East Nusa Tenggara with 177 cases (Keputusan Menteri Kesehatan Republik Indonesia 2020). With the increasing cases of Covid-19, the government is making various prevention efforts one is by doing social distancing. In a statement to The Washington Post on Thursday, Northeastern University professor of political science Daniel Aldrich explained that social distancing is one of the efforts to slow the spread of the coronavirus (Kyne and Aldrich 2020). So it needs to be applied in Indonesia because of the increasing cases of covid. Social distancing applies in all sectors of government, one of which is in the education sector, namely the teaching and learning process in schools is abolished. So that the government, especially the minister of education took steps on how the roots of the education sector remained carried out amid the coronavirus outbreak.

The government's efforts to implement the learning process are by distance learning or online learning or better known as online learning (Khusniyah and Hakim 2019). Minister Nadiem Anwar Makarim issued Circular Letter No. 3 of 2020 on the Education Unit and Number 36962/MPK. A/HK/2020 on The Implementation of Education in the Emergency Period of Coronavirus Disease (COVID-19) then the excitement of learning is carried out online to prevent the spread of coronavirus disease (COVID-19) (Azhar et al. 2020). Online learning is a learning that is done online using learning applications as well as social networks (Kuntarto 2017). Online learning is functional so that students have the freedom to learn and can learn anytime and anywhere without limited space and time (Mustofa et al. 2019). As has been conveyed by Keengwe \& Georgina in his research has stated that technological developments provide changes to the implementation of teaching and learning (Keengwe and Georgina 2012). Information technology can be accepted as a medium in conducting educational processes, including assisting the teaching and learning process, which also involves the search for references and sources of information (Ren, Zhang, and Wang 
2020). In online learning, students can interact with teachers by using video calls or live chat through various android applications such as what's up, zoom, classroom, and others. With this application, students can follow the learning process during online use following the schedule stipulated by each school and involve the teacher concerned. Through the application, teachers explain and discuss materials to students and students can use the subject matter from the internet.

Online learning using these applications does not always run smoothly, there are various obstacles that teachers and students will face in the learning process that is Kouta and signal because without both online learnings can not run smoothly so that it makes online learning often ineffective but the advantages of online learning can be done anytime and anywhere (Purmadi, Samsul Hadi, and Najwa 2018). According to Putra Wijaya in learning at home is not a problem because learning can be done anytime and anywhere, especially already supported by online systems (Suryawan 2020). So the learning process can happen at home, at school as well as in the community. Therefore everything can go well, with the support of facilities such as the internet. So this study aims to analyze the effectiveness of online learning in physics subjects.

\section{METHOD}

This study uses qualitative descriptive methods and data obtained by providing evaluation and observation tests. Evaluation tests are used to view students' learning outcomes in physics subjects using online learning. Evaluation test in the form of a writing test with several 10 essay questions. As for the way the scoring is presented in equation 1 .

$$
\text { score }=\frac{\text { correct number of items }}{\text { total score }} \times 100
$$

The criteria used to improve the completeness of students learning outcomes in online learning are presented in Table 1.

Table 1. Assessment standards category

\begin{tabular}{|c|c|}
\hline Value & Category \\
\hline $0-49$ & Very low \\
\hline $50-69$ & Low \\
\hline $70-79$ & Moderate \\
\hline $80-89$ & High \\
\hline $90-100$ & Very High \\
\hline
\end{tabular}

Then for the category of completed student learning results can be seen in Table 2 .

Table 2. Standard Category of Student Learning Outcomes

\begin{tabular}{cc}
\hline Mastery Level & Category Learning Completeness \\
\hline $0 \leq x<75$ & Incomplete \\
\hline $75 \leq x \leq 100$ & Complete \\
\hline
\end{tabular}

Source: MA NW Kabar 
Then the observation aims to see the effectiveness and activities of students during the learning process of teaching physics through online learning. Assessment competency related to student activities, attention, seriousness, and student skills includes students' skills following the course of the learning process, expressing opinion skills, problemsolving skills, question answering skills provided by teachers. Validation test Observation sheet instruments in this study using construct validation, in this case, validation testing about aspects that will be measured and observation sheets have been approved by experts so that it is said to be valid.

\section{RESULT AND DISCUSSION}

\section{Student evaluation results in physics subjects through online learning}

The results of the descriptive statistical analysis of the grades of the student evaluation results are succinctly presented in Table 3.

Table 3. Statistics of physics evaluation scores through online learning

\begin{tabular}{ccc}
\hline No & Statistics & Statistics Value \\
\hline 1 & Sample & 18 \\
\hline 2 & Ideal score & 100 \\
\hline 3 & Highest score & 72 \\
\hline 4 & Lowest score & 50 \\
\hline 5 & Score range & 18 \\
\hline 6 & Average score & 60,45 \\
\hline 7 & Variance & - \\
\hline 8 & Standard deviation & - \\
\hline
\end{tabular}

Table 4. Distribution and percentage of the student evaluation score

\begin{tabular}{ccccc}
\hline No & Value & Category & Frequency & Percentage (\%) \\
\hline 1 & $0-49$ & Very Low & 2 & $11,1 \%$ \\
\hline 2 & $50-69$ & Low & 11 & $61,1 \%$ \\
\hline 3 & $70-79$ & Moderate & 5 & $27,8 \%$ \\
\hline 4 & $80-89$ & High & - & - \\
\hline 5 & $90-100$ & Very High & - & - \\
\hline \multicolumn{7}{c}{ Amount } & $\mathbf{1 8}$ & $\mathbf{1 0 0 \%}$ \\
\hline
\end{tabular}

Table 5. The decryption of student evaluation results

\begin{tabular}{cccc}
\hline Score Interval & Category & Frequency & Percentage (\%) \\
\hline $0 \leq x<75$ & Incomplete & 13 & $72,2 \%$ \\
\hline $75 \leq x<100$ & Complete & 5 & $27,8 \%$ \\
\hline
\end{tabular}

Judging from Table 3, the statistical results of student evaluation scores that the highestscoring students are 72. Students have only a minimum standard score of KKM and students who get completed grades are only 5 students or $27.8 \%$ and who do not complete 13 students or $72.2 \%$. Judging by Table 5 that more students are not complete, it can be said that students have difficulty in learning using online, online physics learning causes interaction between students and teachers is not maximal, so the teacher's explanation is not understood by students and students are required to learn 
independently, in addition to physics learning using online at MA NW news has a quality of learning that is not optimal due to some things, namely the lack of facilities and facilities supporting online learning such as the internet. It was also explained in Hendrastomo's research that the availability of internet access is very necessary for elearning because these learning characteristics always use and utilize the internet network (Hendrastomo 2008).

\section{Observation of online learning students' activities}

Observation sheets are created to obtain data on the effectiveness of online learning (Rohmawati 2015). Observations are made by observing activities conducted by students during the teaching-learning process. Data is obtained from post-test results at each end of the meeting. The results obtained can be seen in Table 6 .

Table 6. Description of students' activities during online learning

\begin{tabular}{cccccccc}
\hline No & Student activities & \multicolumn{3}{c}{ Meeting to- } & Average & Percentage (\%) \\
\cline { 2 - 8 } & $\mathbf{1}$ & $\mathbf{2}$ & $\mathbf{3}$ & $\mathbf{4}$ & & $14,5 \%$ \\
\hline 1 & $\begin{array}{c}\text { Present at the time } \\
\text { of the learning } \\
\text { process }\end{array}$ & 15 & 12 & 15 & 16 & 14,5 & $13 \%$ \\
\hline 2 & $\begin{array}{c}\text { Students pay close } \\
\text { attention to the } \\
\text { teacher's } \\
\text { explanation during } \\
\text { the study }\end{array}$ & 13 & 12 & 14 & 13 & 13 & \\
\hline 3 & $\begin{array}{c}\text { Students actively } \\
\text { ask and answer } \\
\text { questions during } \\
\text { the learning } \\
\text { process }\end{array}$ & 4 & 3 & 2 & 2 & 2,8 & $2,8 \%$ \\
\hline 4 & $\begin{array}{c}\text { Perform other } \\
\text { activities during } \\
\text { the learning } \\
\text { process }\end{array}$ & 4 & 2 & 3 & 2 & 2,8 & $2,8 \%$ \\
\hline 5 & $\begin{array}{c}\text { Students who } \\
\text { collect } \\
\text { assignments }\end{array}$ & 17 & 13 & 16 & 14 & 15 & $15 \%$ \\
\hline
\end{tabular}

The results of the observation sheet showed that in the first assessment activity, the presence of students in the online learning process from the first week to the fourth week, some students did not attend due to the absence of supporting facilities to follow the online learning process because online learning would not run if the students did not have facilities (internet and HP). The second activity assessment is that during the learning process, students do not all hear and focus on the explanations presented by the teacher due to external and internal factors of the students. The external factor is the environment in which students carry out un-supportive learning to be able to concentrate on doing online learning. The internal factor is that students have not adjusted to online learning. Then, for the third assessment of students' activeness during the learning process, in this case, the students did not interact too much with the teacher, 
because more students did not read the materials that had been given and the lack of teaching materials that could be used as a reference and support the learning. This causes misconceptions between students and teachers and affects students only receiving explanations from teachers and not doing many questions and answer questions. In the fourth assessment, students perform other activities during the learning process, many students do other activities when the online learning process is caused by the environment in which students learn to make the concentration of students following the learning unfocused. Then for the final assessment is the assessment related to students who collect assignments, judging from Table 4 that the percentage of students collecting fewer assignments, is because students are often absent from online learning.

\section{CONCLUSION}

The conclusion that can be drawn in this study is seen from the evaluation of physics learning using online is that there are more than $50 \%$ of students who do not meet KKM standards because of the lack of supporting facilities for the running of online learning well it also happens in student activities during online learning when viewed from the student activity sheet during the online learning process that the student's activity in following physics learning does not go well it is due to several factors namely the first environmental factor, namely the lack of facilities online learning support such as HP internet and laptops. Then the second internal factor of the student itself is that the student has not adjusted to online learning. Online learning is ineffective in pandemics..

\section{ACKNOWLEDGEMENTS (OPTIONAL)}

The researcher thanked the Principal of MA NW Kabar who has allowed researching the school and the research team that has supported this research.

\section{REFERENCES}

Azhar, E.I. et al. 2020. "Edaran Tentang Pencegahan Wabah COVID-19 Di Lingkungan Satuan Pendidikan Seluruh Indonesia." Infect Dis Clin North Am 33: 1-5.

Di Gennaro, Francesco et al. 2020. "Coronavirus Diseases (COVID-19) Current Status and Future Perspectives: A Narrative Review." International Journal of Environmental Research and Public Health 17(8).

Hendrastomo, Grendi. 2008. "Dilema Dan Tantangan Pembelajaran E-Learning 1 (The Dilemma and the Challenge Of." Majalah Ilmiah Pembelajaran 4: 1-13. http://staff.uny.ac.id/sites/default/files/132318574/Dilema dan Tantangan Pembelajaran Elearning ok.pdf.

Keengwe, Jared, and David Georgina. 2012. "The Digital Course Training Workshop for Online Learning and Teaching." Education and Information Technologies 17(4): 365-79.

Keputusan Menteri Kesehatan Republik Indonesia. 2020. "Keputusan Menteri Kesehatan Republik Indonesia Nomor HK.01.07/MenKes/413/2020 Tentang 
Pedoman Pencegahan Dan Pengendalian Corona Virus Disease 2019 (Covid19)." MenKes/413/2020 2019.

Khusniyah, Nurul Lailatul, and Lukman Hakim. 2019. "Efektivitas Pembelajaran Berbasis Daring: Sebuah Bukti Pada Pembelajaran Bahasa Inggris.” Jurnal Tatsqif 17(1): 19-33.

Kuntarto, Eko. 2017. "Keefektifan Model Pembelajaran Daring Dalam Perkuliahan Bahasa Indonesia Di Perguruan Tinggi." Journal Indonesian Language Education and Literature 3(1): 53-65. http://www.syekhnurjati.ac.id/jurnal/index.php/jeill/\%0APEMBELAJARAN.

Kyne, Dean, and Daniel P. Aldrich. 2020. "Capturing Bonding, Bridging, and Linking Social Capital through Publicly Available Data." Risk, Hazards and Crisis in Public Policy 11(1): 61-86. http://dx.doi.org/10.1002/rhc3.12183.

Mustofa, Mokhamad Iklil, Muhammad Chodzirin, Lina Sayekti, and Roman Fauzan. 2019. "Formulasi Model Perkuliahan Daring Sebagai Upaya Menekan Disparitas Kualitas Perguruan Tinggi." Walisongo Journal of Information Technology 1(2): 151.

Purmadi, Ary, M Samsul Hadi, and Luin Najwa. 2018. "Pengembangan Kelas Daring Dengan Penerapan Hybrid Learning Menggunakan Chamilo Pada Matakuliah Pendidikan Kewarganegaraan Developing Daring Class With Hybrid Learning Application Using Chamilo on Civics Education Courses." Jurnal Edcomtech 3(2): 135-40. http://journal2.um.ac.id/index.php/edcomtech/article/view/5467.

Ren, Jun-ling, Ai-hua Zhang, and Xi-jun Wang. 2020. "Profiling Teachers' Readiness for Online Teaching and Learning in Higher Education:Who's Ready?" Pharmacological Research: 104743. https://doi.org/10.1016/j.phrs.2020.104743.

Rohmawati, Afifatu. 2015. "Efektivitas Pembelajaran.” Jurnal Pendidikan Usia Dini 9(1): 15-32.

Sethy, Prabira Kumar, Santi Kumari Behera, Pradyumna Kumar Ratha, and Preesat Biswas. 2020. "Detection of Coronavirus Disease (COVID-19) Based on Deep Features and Support Vector Machine." International Journal of Mathematical, Engineering and Management Sciences 5(4): 643-51.

Suryawan. 2020. "Customary Village-Based State Policies in the Time of the Covid-19 Pandemic." (4).

WHO. 2020. Corornavirus Disease 2019 Situation Report-32. World Health Organization.

Yuliana. 2020. "Corona Virus Diseases (Covid-19): Sebuah Tinjauan Literatur.” Parque de los afectos. Jóvenes que cuentan 2(February): 124-37. 